Article

\title{
A Wild Fomes fomentarius for Biomediation of One Pot Synthesis of Titanium Oxide and Silver Nanoparticles for Antibacterial and Anticancer Application
}

\author{
Suriya Rehman $1, * \oplus$, Romana Farooq ${ }^{2}$, Rabindran Jermy ${ }^{3}$, Sarah Mousa Asiri ${ }^{4}$, \\ Vijaya Ravinayagam ${ }^{5}$, Reem Al Jindan ${ }^{6}$, Zainab Alsalem ${ }^{1}$, Manzoor A. Shah ${ }^{2}$, Zafar Reshi ${ }^{2}$, \\ Hussein Sabit ${ }^{7}$ and Firdos Alam Khan ${ }^{8}$ \\ 1 Department of Epidemic Disease Research, Institute for Research \& Medical Consultations (IRMC), \\ Imam Abdulrahman Bin Faisal University, Dammam 31441, Saudi Arabia \\ 2 Department of Botany, University of Kashmir, Srinagar 190006, India \\ 3 Department of Nano-Medicine Research, Institute for Research \& Medical Consultations (IRMC), \\ Imam Abdulrahman Bin Faisal University, Dammam 31441, Saudi Arabia \\ 4 Department of Biophysics, Institute for Research \& Medical Consultations (IRMC), Imam Abdulrahman Bin \\ Faisal University, Dammam 31441, Saudi Arabia \\ 5 Deanship of Scientific Research and Department of Nano-Medicine Research, Institute for Research \& \\ Medical Consultations (IRMC), Imam Abdulrahman Bin Faisal University, P.O. Box 1982, Dammam 31441, \\ Saudi Arabia \\ 6 Department of Microbiology, College of Medicine, Imam Abdulrahman Bin Faisal University, \\ Dammam 31441, Saudi Arabia \\ 7 Department of Genetic Disease Research, Institute for Research \& Medical Consultations (IRMC), \\ Imam Abdulrahman Bin Faisal University, Dammam 31441, Saudi Arabia \\ 8 Department of Stem Cell Research, Institute for Research \& Medical Consultations (IRMC), \\ Imam Abdulrahman Bin Faisal University, Dammam 31441, Saudi Arabia \\ * Correspondence: surrehman@iau.edu.sa or suriyamir@gmail.com; Tel.: +966-532-4256
}

Received: 7 March 2020; Accepted: 11 April 2020; Published: 17 April 2020

check for updates

\begin{abstract}
The present study offers an alternative method for green synthesis of the formation of

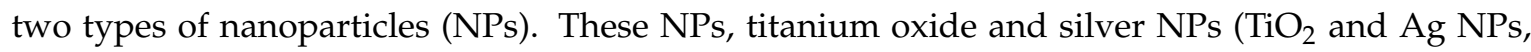
respectively), were obtained from the amalgamation of intracellular extract of a wild mushroom, Fomes fomentarius, with aqueous solutions of titanium isopropoxide and silver nitrate, respectively. F. fomentarius was identified phenotypically and by $18 \mathrm{~S}$ ribosomal RNA gene sequencing (Gene accession no: MK635351). The biosynthesis of $\mathrm{TiO}_{2}$ and $\mathrm{Ag}$ NPs was studied and characterized by X-ray diffraction (XRD), diffuse reflectance UV-Visible spectroscopy (DR-UV), fourier transform infrared spectroscopy (FT-IR), scanning electron microscopy (SEM) and transmission electron microscope (TEM). Success was achieved in obtaining NPs of differing sizes and shapes. The antibacterial and anticancer activity of the NPs was significant with morphological damage being caused by both, although Ag NPs (10-20 nm) were found to have profound effects on bacterial and cancer cells in comparison to $\mathrm{TiO}_{2}$ NPs $(100-120 \mathrm{~nm})$. These metal NPs, synthesized using wild mushrooms, hold a great potential in biomedicinedue to an effective enzyme combination, which permits them to modify different chemical compounds to less toxic forms, which is required for ecofriendly and safe biomaterials.
\end{abstract}

Keywords: antibacterial/anticancer; Fomes fomentarius; green synthesis; nanoparticles; silver/titanium 


\section{Introduction}

Nanoparticles (NPs) possess rare chemical, optical, photoelectrochemical, magnetic and catalytic characteristics, having potential in medicine and other disciplines [1]. Among the vast array of NPs, Ag NPs are the most stable and biocompatible due to their unusual physical and chemical properties. Ag NPs are also known to possess antibacterial, antifungal, antiviral, antioxidant, anti-inflammatory and antitumor activities, and hence they have broad possibilities as use as nano-Ag in biomedicine for antimicrobial drugs, medical devices, medicinal products and cosmetics [2-4]. Inert and nontoxic $\mathrm{TiO}_{2}$ is another economical material that is highly capable of absorbing UV light, due to its high refractive index. $\mathrm{TiO}_{2}$ NPs are extensively used in cosmetics, paper, paints, food colorants, inks and toothpaste, due to their white pigment and the fact that they are environmentally friendly catalysts [5]. Various physicochemical and biological properties, as well as the toxicity of NPs, are because of the shape and size of NPs [6-8]. The control of NP morphology with desired characteristics demands new measures in techniques of synthesis involving chemical and green synthesis routes. Recently, AgNPs $(\sim 15 \mathrm{~nm})$ were reported using chemical methods through an ultrasonic assisted route for metal-based conductive ink technology. The chemical method used ascorbic acid and glucose as a mixed reducing agent in poly(N-vinylpyrrolidone) solution [9]. Nano $\mathrm{TiO}_{2}$ with major anatase phase ( $\left.>94 \%\right)$ has been reported using a chemical vapor condensation technique. The experiments involve the introduction of a titanium source (Titanium tetraisopropoxide), argon and air in the vapor phase into an alumina tube for subsequent thermal decomposition to produce TiO NPs [10]. Nanoparticle preparation through green synthesis is the emerging field of research that provides an alternative route to conventional chemical methods that use tedious experimental set-up and eco-unfriendly chemicals. Present times have identified an increased adoption of eco-friendly approaches for the synthesis of NPs, such as the use of plants, bacteria, fungi and algae, etc. [11-15]. AgNPs and starch nanoparticles has been reported using cheap, biodegradable resources such as pomegranate seed (Punica granatum L.) and starch for food packing film application. The study shows that sunlight can be effectively used as a photo-reducing agent to convert silver nitrate sources to AgNPs [16]. Biosynthesis of AgNPs with a particle size of about $15 \mathrm{~nm}$ was reported using two white rot fungal strains (Ganoderma enigmaticum and Trametes ljubarskyi). The nanoparticle synthesis via the extracellular biosynthetic route using organism extract as reducing agents was found to be economically viable with high growth rates in lab scales [17]. Green synthesis of $\mathrm{TiO}_{2}$ NPs was reported using Azadirachta indica leaf extract. The presence of active components (terpenoids, flavonoids and proteins) was shown to stabilize the crystalline nanoparticle formation in sizes ranging between 15-50 $\mathrm{nm}$ [18].

In this regard, the use of fungi for nanoparticle synthesis, particularly the unexplored higher fungi (mushroom) is still in its infancy. The most familiar species of mushrooms belong to the group Basidiomycota, polyporales, which constitutes an order of about 1800 species of fungi in the division [19]. Polypore, a term used for basidiocarp-producing fungi, appears tough and leathery, typically large $(>3 \mathrm{~cm})$, and found mostly on live and dead trees [20]. These basidiomycetes are nonpathogenic, nontoxic and can be grown in pure cultures, hence, they are favorable for the biosynthesis of NPs [21]. The use of basidiomycetes for NP synthesis has not been extensively explored, as compared to synthesis using lower fungi and bacteria [22]. Herein, we report the mediation of culture filtrate of wild basidiomycetes, F. fomentarius for the green synthesis of $\mathrm{TiO}_{2}$ and $\mathrm{AgNPs}$ and subsequent in vitro studies for antibacterial and anticancer activity.

\section{Experimental}

\subsection{Collection, Phenotypic and Genotypic Studies of F. fomentarius}

For the collection of sporocarps, a standard method was followed [20]. Photographs were taken by a Nikon D5300 DSLR Camera (Nikon, Tokyo, Japan) with a zoom lens of 18-140 VR (data of sampling in supplementary file). Passport data and the microhabitat characteristics of collected samples has 
been recorded in the field book. Samples were properly labeled, given a voucher number and carried to the laboratory for detailed morphometric examination.

Collected specimens were identified by keen observation of structures like pileus, stipe, their shape, structure, gill attachment, etc., using standard keys (e.g., Mycokey, Index fungoram etc.) field guides and manuals. The samples were dried and deposited at the herbarium of the Centre for Biodiversity and Taxonomy, University of Kashmir, J\&K, India. Microscopic features and measurements were made from slides that were prepared and stained with lactophenol cotton Blue, $2 \% \mathrm{KOH}$ and Melzer's reagent. For examination, the spores were tapped off the razor blade onto a clean and a drop of $\mathrm{KOH}$ or Melzer's reagent was added. Observation and photographs were captured at magnification between $\times 40$ to $\times 100$ using a Nikon Eclipse $80 \mathrm{i}$ microscope and phase contrast illumination (Nikon, Tokyo, Japan).

\subsubsection{DNA Isolation and PCR}

DNA extraction was done using the manual CTAB method (cetyl trimethylammonium bromide) [23]. The extracted DNA was dissolved and preserved in TE (Tris-EDTA) buffer. The amplification was carried out for internal transcribed spacer (ITS) regions using the ITS1 and ITS4 in a PCR System Thermocycler Applied Biosystems with following parameters-10 min of initial denaturation at $95{ }^{\circ} \mathrm{C}, 35$ cycles at $95{ }^{\circ} \mathrm{C}$ for $1 \mathrm{~min}, 54{ }^{\circ} \mathrm{C}$ for $30 \mathrm{~s}$ and $72{ }^{\circ} \mathrm{C}$ for $2 \mathrm{~min}$, followed by extension at $72{ }^{\circ} \mathrm{C}$ for $10 \mathrm{~min}$. The purification of amplified products was done and sequenced with the same primers. The DNA sequences were submitted to GeneBank and analyzed for homology using BLAST on NCBI [24] (Table 1).

\subsubsection{Sequence and Phylogeny Analysis}

Wild mushroom was identified by ribosomal gene analysis. The small subunit sequences were aligned with additional sequences downloaded from NCBI GenBank (http//ncbi.nim.nih.gov) using BioEdit Sequence Alignment Editor (version 7.2.5) [25]. The sequence alignments and phylogenetic analysis were performed using MEGA 10 software (Tamura et al., 2011). Phylogeny was studied on ITS -18SrRNA genes by maximum likelihood method. Initial alignment was done using Clustal W software for maximum alignment and minimum gaps. The tree was generated by using the program DNADIST and NEIGHBOR from PHYLIP 3.69 [24].

\subsection{Biosynthesis of $\mathrm{TiO}_{2}$ and $\mathrm{AgNPs}$ Using Fomes Fomentarius}

The synthesis of $\mathrm{TiO}_{2}$ and AgNPs was conducted using the extract of $F$. fomentarius by adopting a green synthesis method [23]. The F. fomentarius sample was dried to obtain powder (10 g), which was further mixed with $100 \mathrm{~mL}$ of millipore water and sonicated for 25-30 min. The mixture was further centrifuged at $4000 \mathrm{rpm}$ to obtain the clarified solution. Subsequently, solution was filtered and stored at $4{ }^{\circ} \mathrm{C}$. A total of $10 \mathrm{~mL}$ of filtrate was mixed with $1 \mathrm{mM} \mathrm{AgNO}(100 \mathrm{~mL})$ and put at room temperature on a shaker for agitation under observation, until the appearance of color change (10 $\mathrm{min})$. A similar procedure was followed for $\mathrm{TiO}_{2} \mathrm{NPs}$, where $100 \mathrm{~mL}$ of $1 \mathrm{mM}$ Titanium (IV) isopropoxide was used as a source solution.

\subsection{Characterization of Biosynthesized $\mathrm{TiO}_{2}$ and $\mathrm{Ag} \mathrm{NPs}$}

The crystalline phase of $\mathrm{TiO}_{2}$ and $\mathrm{Ag}$ NPs was measured using a benchtop X-ray powder diffractometer MiniFlex 600 (Rigaku, Shibuya, Tokyo, Japan). The sample was measured in 2 theta range $5-80^{\circ}$, with step size of $0.02^{\circ}$ and scan rate of $1^{\circ} / \mathrm{min}$. The coordination environment of $\mathrm{TiO}_{2}$ and Ag NPs were analyzed using diffuse reflectance UV-Visible spectroscopy (V-750, JASCO). The sample for diffuse reflectance was prepared by dispersing the sample in a spherical disc with an integrated sphere (60 $\mathrm{mm}$ dia, ISV-922). After pressing, the sample with $0.5 \mathrm{~mm}$ thickness was scanned between wavelength range $200-870 \mathrm{~nm}$. The $\mathrm{TiO}_{2}$ and $\mathrm{Ag}$ NPs functional groups were analyzed using fourier transform infrared spectroscopy equipped with attenuated total reflectance (ATR) (Perkin 
Elmer, Arcata, CA, USA). The surface morphology, distribution and features of $\mathrm{TiO}_{2}$ and $\mathrm{Ag}$ NPs were studied using scanning electron microscopy (SEM) (Inspect S50) and transmission electron microscope (TEM) (Morgagni 268). For TEM analysis, samples were prepared by dispersing in ethanol followed by shaking in an ultrasonicator for $20 \mathrm{~min}$, and then a suspended drop was dried at room temperature on the carbon-coated copper grid [15].

\subsection{Antibacterial Activity of Biosynthesized NPS}

Common pathogenic bacteria Escherichia coli (E. coli ATCC35218) and Staphylococcus aureus (S. aureus ATCC29213) were used for the antibacterial activity of synthesized $\mathrm{TiO}_{2}$ and Ag NPs by agar well diffusion. The bacterial strains were maintained on nutrient agar media (NA). In preparation for the antibacterial study, a homogeneous water suspension of the NPs was prepared by sonication for $15-20 \mathrm{~min}$ at $30^{\circ} \mathrm{C}$. Test organisms grown at $37^{\circ} \mathrm{C}$ for $18 \mathrm{~h}$ in Mueller Hinton (MHB) were adjusted to the cell density of $10^{6} \mathrm{CFU} / \mathrm{mL}$. A total of $100 \mu \mathrm{L}$ of adjusted inoculum of each bacterial strain was inoculated on the MHA plates. After 20-30 min, the dried plates were punched for wells using the sterile borer. A total of $50 \mu \mathrm{L}$ of $\mathrm{TiO}_{2} \mathrm{NP}$ and $\mathrm{Ag} \mathrm{NP}(100 \mu \mathrm{g} / \mathrm{mL})$ suspension was placed into the wells. Sterile water was used as a negative control. This was followed by the incubation at $37^{\circ} \mathrm{C}$ for $24 \mathrm{~h}$. The activity of the synthesized NPs was evaluated by measuring the zone of inhibition zone around the wells in millimeters (mm) [15].

\subsection{Study of Topological Changes in Treated Bacteria by SEM}

Additionally, the treated E. coli and S. aureus were studied by SEM for the morphological and physiological alteration caused by NPs. Precisely, adjusted bacterial cells were treated with $100 \mu \mathrm{g} / \mathrm{mL}$ of $\mathrm{TiO}_{2}$ and $\mathrm{Ag}$ NPs and further incubated at $37^{\circ} \mathrm{C}$ for overnight. Later, the incubated mixture was centrifuged at 12,000 rpm for $10 \mathrm{~min}$ for treated and untreated cells. The harvested cells were thrice washed using PBS and primarily fixed with 2.5\% glutaraldehyde for $4 \mathrm{~h}$, followed by fixation with $1 \%$ osmium tetroxide for $2 \mathrm{~h}$. Cells were washed multiple times and further dehydrated by varying concentrations of ethanol $(50 \%, 70 \%, 90 \%, 100 \%)$. The cells were placed onto the aluminum stubs and dried using a desecrator. Finally, gold coating was done and cells were examined by SEM at an accelerating voltage of $20 \mathrm{kV}$ [26].

\subsection{Cytotoxic Activity}

\subsubsection{Cell Culture \& Treatments}

Human colorectal carcinoma cells (HCT-116) were used for the study. DMEM medium was used, which was supplemented with 10\% fetal bovine serum (FBS); (10\%) L-glutamine; 10\% selenium chloride; $120 \mu \mathrm{g} / \mathrm{mL}$ and streptomycin; and $120 \mathrm{Unit} / \mathrm{mL}$ penicillin in a $5 \% \mathrm{CO}_{2}$ incubator (Thermo Scientific Heracell-150, Langenselbold Germany) at a temperature of $37^{\circ} \mathrm{C}$. The cells with more than $70-80 \%$ confluency were used for the $\mathrm{TiO}_{2}$ and $\mathrm{Ag}$ NPs treatments. The treatment of HCT-116 cells was carried out with different concentrations of NPs ranging from 0.5 to $8.0 \mu \mathrm{g} / \mathrm{mL}$. The cells were analyzed after a time span of $48 \mathrm{~h}$. The experiment was carried out in triplicate for statistical analysis [27].

\subsubsection{Cancer Cell Morphology}

The cell morphology of untreated and treated HCT-116 cells was examined post-48 h under an inverted microscope (TS100F-Eclipse, Nikon, Tokya, Japan) and compared under 200× magnification.

\subsubsection{Cytotoxicity by MTT Assay}

The cells with confluency of 70-80\% in 96-well cell culture plates were subjected to MTT assay. After $48 \mathrm{~h}$, MTT (5 mg/mL) was added in all the wells and kept for $4 \mathrm{~h}$. Later, DMSO was added and 
the plate was read in an ELISA Plate Reader $570 \mathrm{~nm}$ wavelength (Biotek Instruments, Winooski, VT, USA). The (\%) percentage of cell viability was calculated as per given formula:

$$
\text { Cell Viabilty } \%=(\mathrm{A} / \mathrm{B}) \times 100
$$

A: optical density of nanoparticles, B: optical density of controls.

\subsubsection{Nuclear Staining by DAPI}

The cells were stained with DAPI staining to study the effect of $\mathrm{TiO}_{2} \mathrm{NPs}$ and $\mathrm{Ag}$ NPs on the cell nucleus. After $48 \mathrm{~h}$, the treated and untreated HCT-116 cells were immersed in ice-cold (4\%) paraformaldehyde. Later, the cells were added with Triton X-100 and prepared in PBS for 5 min to premetallize the cell membrane. The cells were stained using DAPI $(5 \mu \mathrm{g} / \mathrm{mL})$ in PBS, prepared in dark. Washing with Triton X-100 was done, followed by examining the nuclear morphology under confocal scanning microscope (Zeiss, Jena, Germany) equipped with a digital camera [27].

\section{Results and Discussion}

\subsection{Phenotypic and Genotypic Studies of F. fomentarius}

Various wild mushrooms are recorded to have potential anticancer and antioxidant properties, specifically, edible mushrooms possess several bioactive molecules with unique and diverse bioactivities, like antimicrobial, anti-inflammatory, antioxidant, antitumor and anticancer activities [28]. Based on these reports, an attempt was made to use $F$. fomentarius extracts as reducing agents for the synthesis of $\mathrm{TiO}_{2}$ and AgNPs, which was collected from an angiosperm host in the natural forest of Kashmir valley, India. This wild mushroom has been recently reported to possess anti-inflammatory, antioxidant, antinociceptive, antidiabetic, antibacterial, and cytotoxic activities.

The upper side of $F$. fomentarius is zoned concentrically with wavy furrows. The basidiomes are perennial, leathery and hoof-shaped. The above surface is smooth and zoned, having a thick crust, and the lower surface is pale brown and concave in shape (Figure 1a). The microscopic observations were mainly focused on basidiospores, which were cylindrical to ellipsoid in shape, measuring $36 \times 1.5$ to $2 \mu \mathrm{m}$. Spores are bilaterally asymmetrical (inequilateral), as they are forcibly discharged from the basidium for dispersal. The shape of the hilar appendix is beaked. The spore apex is rounded. Spore ornamentation is smooth (Figure $1 \mathrm{~b}$ ).

The ITS1-ITS4 sequences of F. fomentarius were deposited in the NCBI Gene Bank under accession number MK635351. The phylogenetic relationships with related species are shown in Table 1 (phylogenetic tree is included as supplementary information).

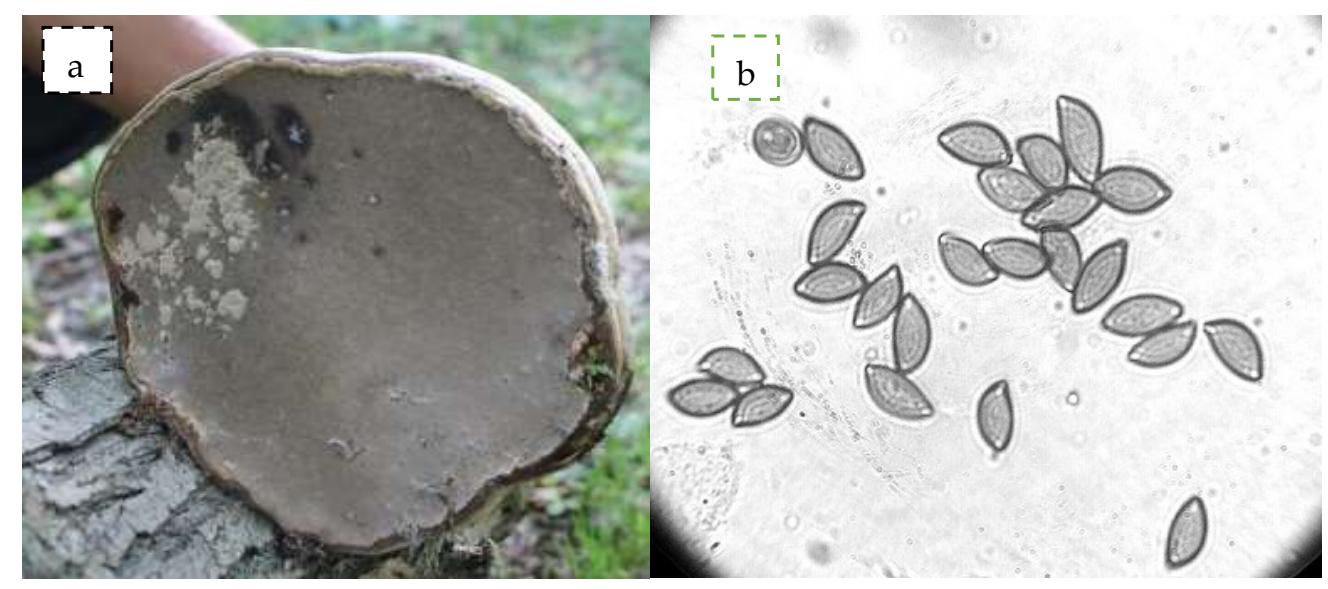

Figure 1. Photographs of brown rot basidiomycetes-F. fomentarius, (a) under view showing pores (b) basidiospores at $100 \times$. 
Table 1. Gene Bank accession numbers and top BLAST match sequences of the mushroom isolates along with maximum identity and query coverage.

\begin{tabular}{cccc}
\hline \multirow{2}{*}{ Accession Number } & \multicolumn{3}{c}{ BLAST Match Sequence } \\
\cline { 2 - 4 } & Reference Accession Number & Coverage & Maximum Identity \\
\hline \multirow{3}{*}{ MK635351 } & JX126894.1 Fomes fomentarius & $100 \%$ & $100 \%$ \\
\cline { 2 - 4 } & KU1391991.1 Fomes fomentarius & $100 \%$ & $100 \%$ \\
\cline { 2 - 4 } & MK9101131 Fomes fomentarius & $100 \%$ & $99.82 \%$ \\
\cline { 2 - 4 } & KU863082.1 Fomes fomentarius & $100 \%$ & $99.82 \%$ \\
\cline { 2 - 4 } & KX065943.1 Fomes fomentarius & $100 \%$ & $99.82 \%$ \\
\hline
\end{tabular}

\subsection{Characterization of $\mathrm{TiO}_{2}$ and $\mathrm{AgNPS}$}

Figure 2a,b shows the X-ray diffraction (XRD) spectra of $\mathrm{Ag}$ and $\mathrm{TiO}_{2} \mathrm{NPs}$. In the case of $\mathrm{Ag} \mathrm{NPs}$, clear diffraction lines corresponding to (111), (200) and (220) planes were observed, indicating the presence of face-centered cubic ( $f_{c c}$ ) crystals. The presence of an additional peak at a 2-theta value of about 51.2 and 52.3 and additional less indexed peaks can be ascribed due to $\mathrm{AgNO}_{3}$ compounds present in the extract. Khatami et al. (2018) found a similar additional peak and ascribed it to the additional compounds present in the dried grass extract [29]. In the case of $\mathrm{TiO}_{2} \mathrm{NPs}$, the formation of crystalline $\mathrm{TiO}_{2}$ was observed with sharp peaks corresponding to the rutile phase.

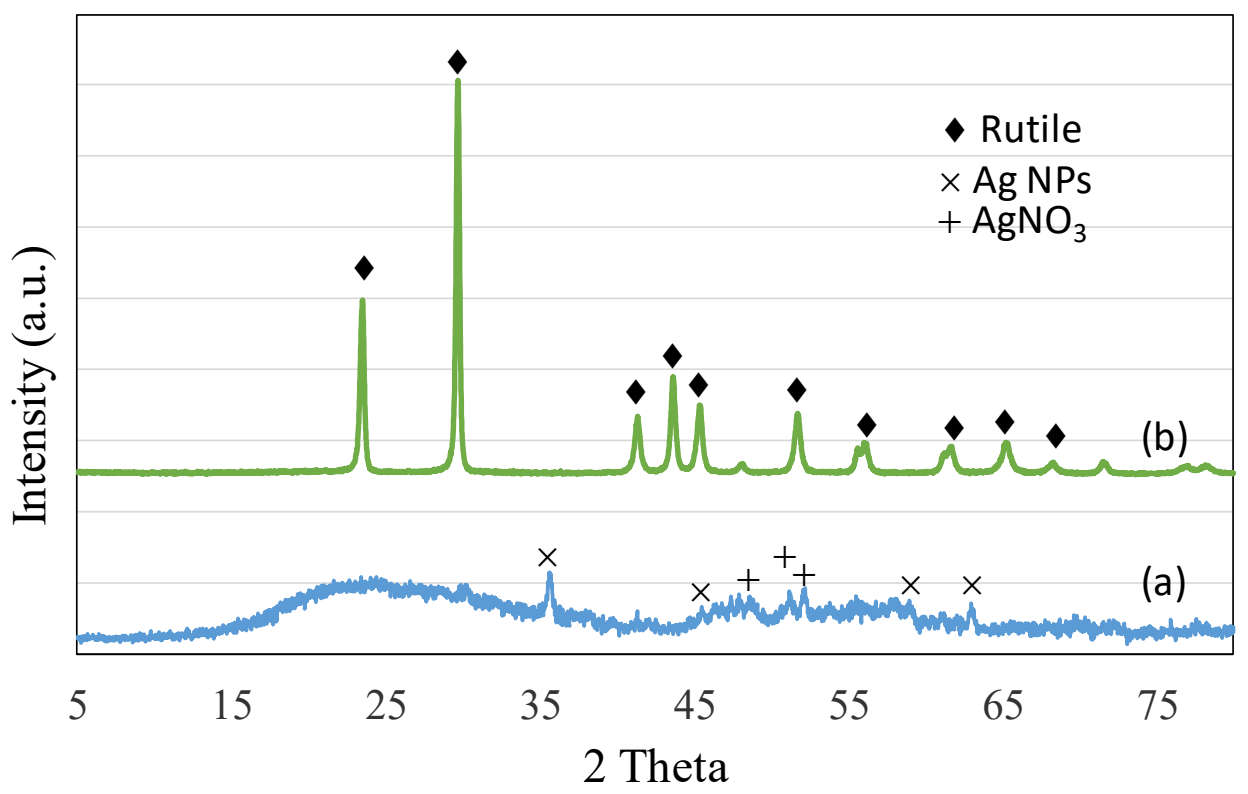

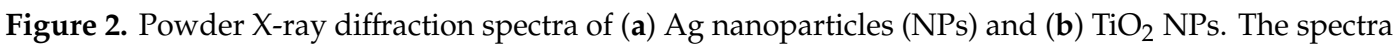
(a) represents Ag NPs with FCC structure and (b) shows $\mathrm{TiO}_{2} \mathrm{NPs}$ crystals with rutile phase

Diffuse reflectance UV-visible spectra were recorded to study the coordination site of titanium oxide and Ag NPs in the extract. Figure 3a,b shows the diffuse reflectance spectra of Ag NPs and $\mathrm{TiO}_{2}$ NPs. The synthesized silver nanoparticle showed the presence of different oxidation states of $\mathrm{Ag}$ species (Figure 3a). The presence of three clear bands was observed at 220, 350 and $410 \mathrm{~nm}$. The small band at $220 \mathrm{~nm}$ was ascribed due to $\mathrm{Ag}^{+}$, while a broad band at 350 and $410 \mathrm{~nm}$ showed the dominant species of $\mathrm{Ag}_{\mathrm{n}}{ }^{ }{ }^{+}$nanoclusters and $\mathrm{Ag}^{0}$ species. In the case of $\mathrm{TiO}_{2}$, the band at $220 \mathrm{~nm}$ shows the presence of isolated $\mathrm{Ti}(\mathrm{IV})$ species, while the octahedral Ti species was found at about $300 \mathrm{~nm}$. In line with XRD analysis, the sample $\mathrm{TiO}_{2}$ showed the presence of a rutile (titania) phase at about $410 \mathrm{~nm}$ and 
expanded to show the presence of agglomeration among $\mathrm{TiO}_{2}$ nanoparticles with broad absorption extending up to $700 \mathrm{~nm}$.

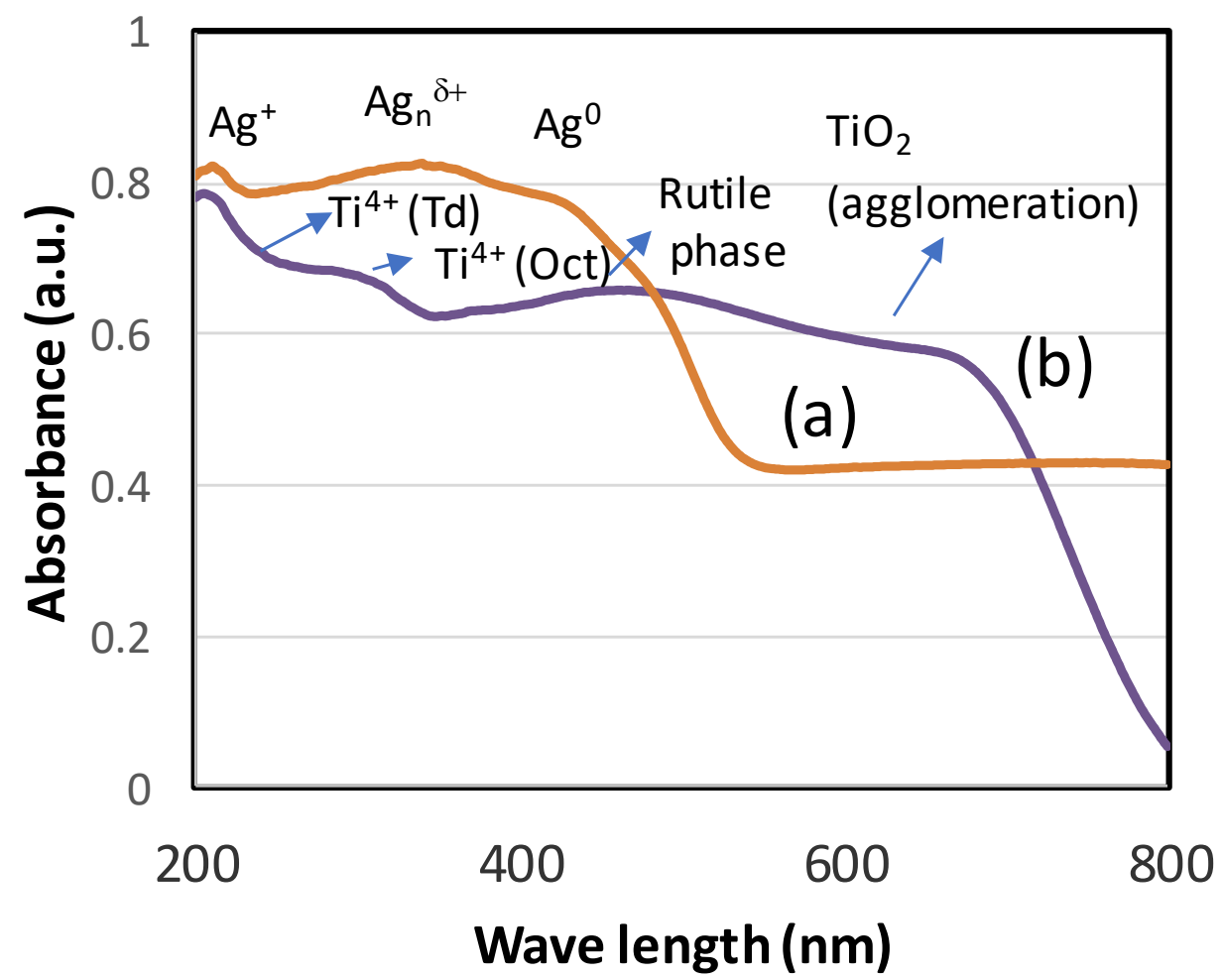

Figure 3. Diffuse reflectance UV-visible spectra of (a) Ag NPs and (b) $\mathrm{TiO}_{2} \mathrm{NPs}$. The spectra (a) shows existence of $\mathrm{Ag}+, \mathrm{Ag}_{\mathrm{n}}{ }^{\delta+}$ and $\mathrm{Ag}^{0}$ species and (b) shows isolated $\mathrm{Ti}(\mathrm{IV})$, Octahedral Ti and rutile phase of $\mathrm{TiO}_{2}$ NPs.

Figure 4a,b shows the Fourier transform infrared (FT-IR) spectroscopy of $\mathrm{Ag}$ and $\mathrm{TiO}_{2} \mathrm{NPs}$. The presence of active components like flavonoids and alkaloids in the extract are reported to play an active role in reducing $\mathrm{Ag}^{+}$ions of a metal source to Ag NPs. A reduction in peak intensity and peak position compared to the extract indicates an effective nanoparticle formation [30]. In the case of mushroom extract, generally an intense peak appears corresponding to the presence of an amino and hydroxyl functional group [31]. In our case, Ag NPs exhibited a broad peak at about $3290 \mathrm{~cm}^{-1}$ corresponding to hydroxyl $(-\mathrm{OH})$ and $\mathrm{N}-\mathrm{H}$ stretching of primary amines (Figure 4a). A methylene C-H stretching peak was observed at $2940 \mathrm{~cm}^{-1}$. The presence of an asymmetrical C-O stretching peak was observed at $1655 \mathrm{~cm}^{-1}$. The presence of aromatic and aliphatic amines (C-N) was clearly seen with an intense absorption peak at about 1406 and $1000 \mathrm{~cm}^{-1}$. In the case of $\mathrm{TiO}_{2} \mathrm{NPs}$, comparatively less intense peak absorption values were observed between $3000-3680 \mathrm{~cm}^{-1}$ corresponding to $-\mathrm{C}-\mathrm{H}$ symmetric stretching $\left(2956 \mathrm{~cm}^{-1}\right)$ and the hydroxyl group of $\mathrm{TiO}_{2}\left(3420 \mathrm{~cm}^{-1}\right)$. The presence of a hydroxyl band Ti-OH was clearly observed at $1630 \mathrm{~cm}^{-1}$. Further, the presence of $\mathrm{TiO}_{2} \mathrm{NPs}$ was confirmed with absorption peaks between $766-1630 \mathrm{~cm}^{-1}$, corresponding to Ti-O, aliphatic $\mathrm{C}-\mathrm{N}$, and aromatic $\mathrm{C}=\mathrm{N}$ bands. The study showed the presence of various phytocomponents related to amino, methyl and hydroxyl groups present in the mushroom sample assist in transformation into silver and titanium oxide NPs. 


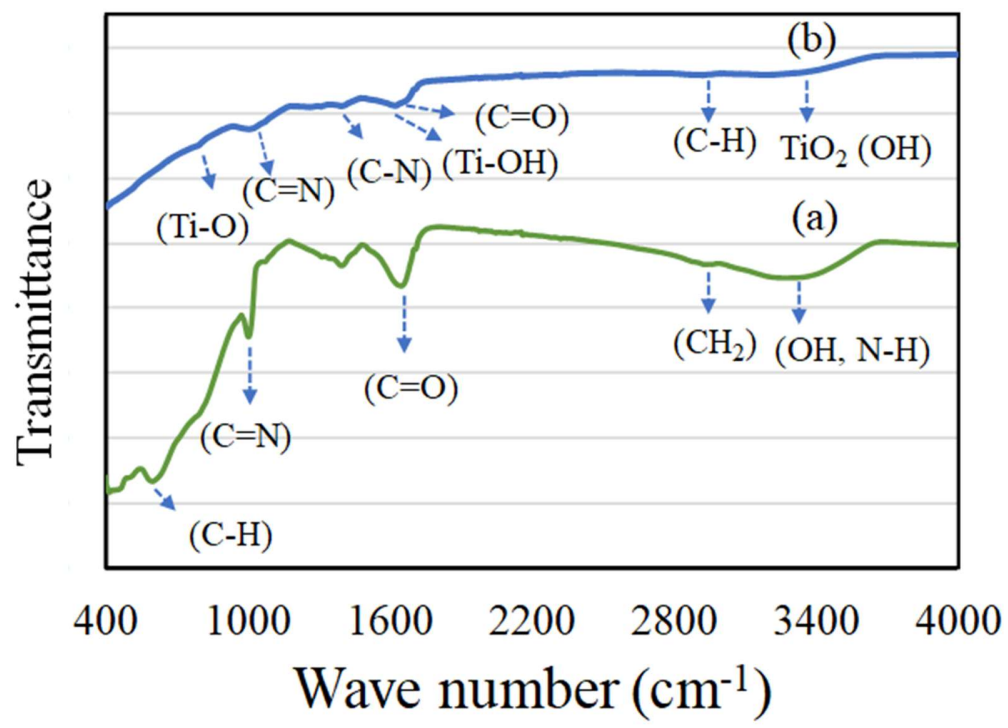

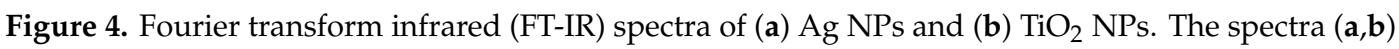
shows the presence of various phytocomponents related to amino, methyl and hydroxyl groups assist in $\mathrm{Ag}$ and $\mathrm{TiO}_{2} \mathrm{NPs}$ formation.

Figure 5 depicts SEM and TEM morphology of $\mathrm{TiO}_{2}$ and Ag NPs. Figure 5 a shows that $\mathrm{TiO}_{2}$ NPs were uniformly distributed on the surface with irregular shape and formation of aggregated NPs. The observed micrograph shows aggregates of $\mathrm{TiO}_{2} \mathrm{NPs}$ with a rough surface. Meanwhile, the TEM micrograph of $\mathrm{TiO}_{2}$ corresponded with SEM results, which showed that the prepared NPs are asymmetrical particles with an average diameter of around 80-120 nm. For Ag NPs, SEM morphology (Figure 5c) illustrated an almost spherical shape with smooth surface conglomerated with each other [32]. TEM showed small spherical NPs distributed with an average diameter of around $10-20 \mathrm{~nm}$.
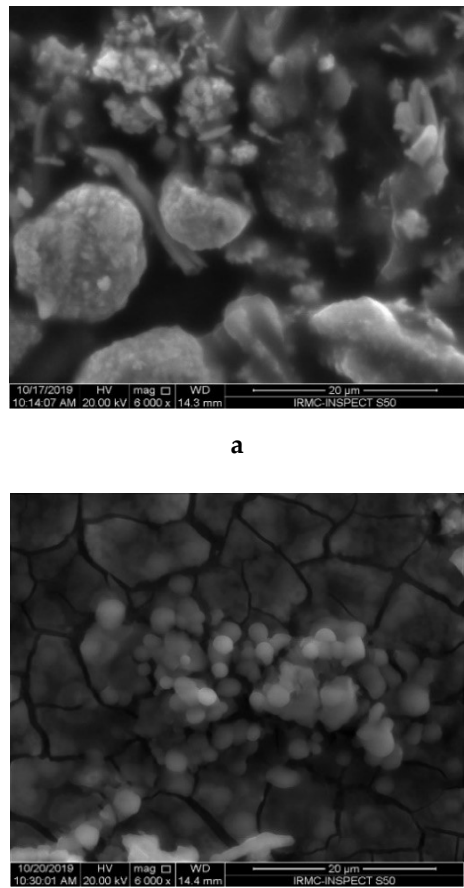

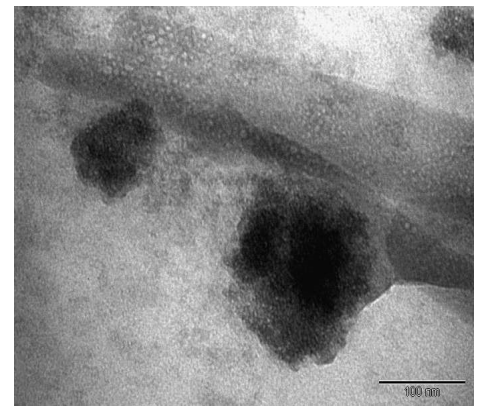

b

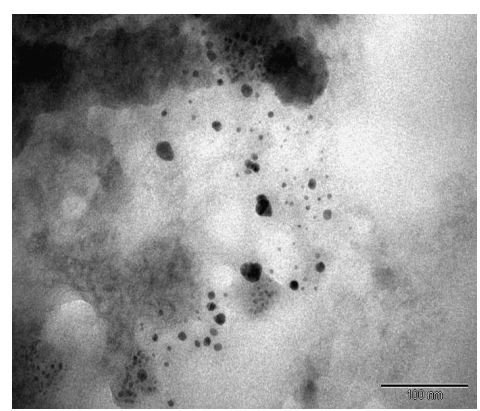

d

Figure 5. Morphological study of $\mathrm{Ag}$ and $\mathrm{TiO}_{2} \mathrm{NPs}$-(a) scanning electron microscopy (SEM) and (b) transmission electron microscope (TEM) images of $\mathrm{TiO}_{2}$ NPs; (c) SEM and (d) TEM images of Ag NPs. 
Previous studies have found mushroom species, which mediate the formation of NPs, contain adequate proteins and enzymes and are an important group of fungi, with medicinal properties [33]. However, the exact mechanism involved in the conversion of NPs via mushroom extract is still unclear and needs a detailed study.

\subsection{Antibacterial Activity of Synthesized NPS}

The antibacterial activity of $\mathrm{TiO}_{2}$ NPs and Ag NPs was performed by an Agar well diffusion method using E. coli and S. aureus. The zone of inhibition was seen for both the gram-positive and gram-negative species against both the tested NPs (Figure 6). E. coli had a clear zone of $15 \mathrm{~mm}$ and $22 \mathrm{~mm}$ in diameter, against $\mathrm{TiO}_{2} \mathrm{NPs}$ and $\mathrm{Ag}$ NPs, respectively. Whereas S. aureus was observed with 11 and $15 \mathrm{~mm}$ of clear zones, against $\mathrm{TiO}_{2}$ NPs and Ag NPs, respectively. The obtained results indicated that both the NPs have significant activity against both bacteria, with the elevated activity obtained against E. coli, when treated with Ag NPs.
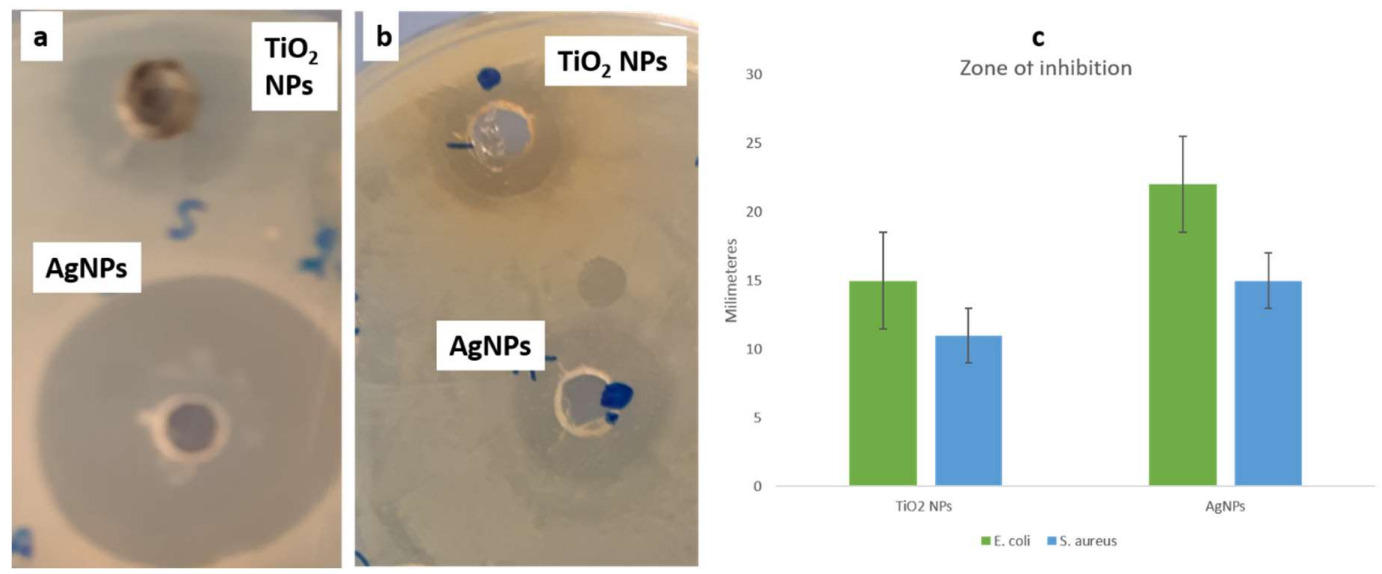

Figure 6. Zone of inhibition by agar well diffusion at $100 \mu \mathrm{g} / \mathrm{mL}$ of NPs; (a) E. coli and (b) S. aureus (c) Graph depicting ZOI.

This study of antibacterial activity of $\mathrm{TiO}_{2} \mathrm{NPs}$ and $\mathrm{Ag}$ NPs against the Gram-negative and Gram-positive bacteria depicted that NPs could arrest the functioning of the cell. Ag NPs are more effective obstructing agents, as silver ions $\left(\mathrm{Ag}^{+}\right)$get released from $\mathrm{Ag}$ NPs and interact with the phosphorus moieties in bacterial DNA, leading to inactivation of replication, therefore preventing growth [33]. The current results agree with several studies conducted previously, pointing towards the antibacterial activity of biosynthesized Ag NPs using mushrooms, however, this is a first report of synthesis of mushroom-mediated $\mathrm{TiO}_{2} \mathrm{NPs}$, to the best of our knowledge.

Nithya and Ragunathan synthesized NPs by Pleurotus sajor-caju, which was studied against $P$. mirabilis and P. Aeruginosa, and recorded the zone of inhibition of 14 and $12 \mathrm{~mm}$, respectively [34]. Manzoor et al. studied Ag NPs through Agaricus bisporus, which is a nutritionally and medicinally important species of mushrooms [31]. Birla et al. recorded enhanced activity of E. coli and P. aeruginosa compared to Staph aureus by Ag NPs synthesized through Phoma glomerata [35]. Additionally, Panáček et al. and Balaji et al. suggested that Ag NPs could be combined with antibiotics for better efficacy against number of pathogenic microbes [36,37].

The present study is also in agreement with the studies conducted by Swathi et al. on $\mathrm{TiO}_{2} \mathrm{NPs}$ synthesized by the green method, against Gram-negative and Gram-positive bacteria, indicating the elevated activity against Gram negative organism [23,38].

Topological changes caused by synthesized NPs in E. coli and S. aureus were further evaluated by SEM. The untreated (control) E. coli cells appeared to be rod-shaped, having a consistent and intact cell surface (Figure 7a). However, treated E. coli cells were no longer intact, with abnormal and irregular appearance at the cellular surfaces (Figure $7 \mathrm{~b}$ ). The cells treated with Ag NPs appeared more affected 
than those of the $\mathrm{TiO}_{2}$ NPs (Figure 7c). The E. coli cells treated with $\mathrm{TiO}_{2} \mathrm{NPs}$ showed mild alteration, whereas E. coli cells were severely damaged by Ag NPs. This was due to pit formation and distortion of cellular wall and membrane, reflecting the loss of the cellular integrity, which possibly cause the bacterial death.
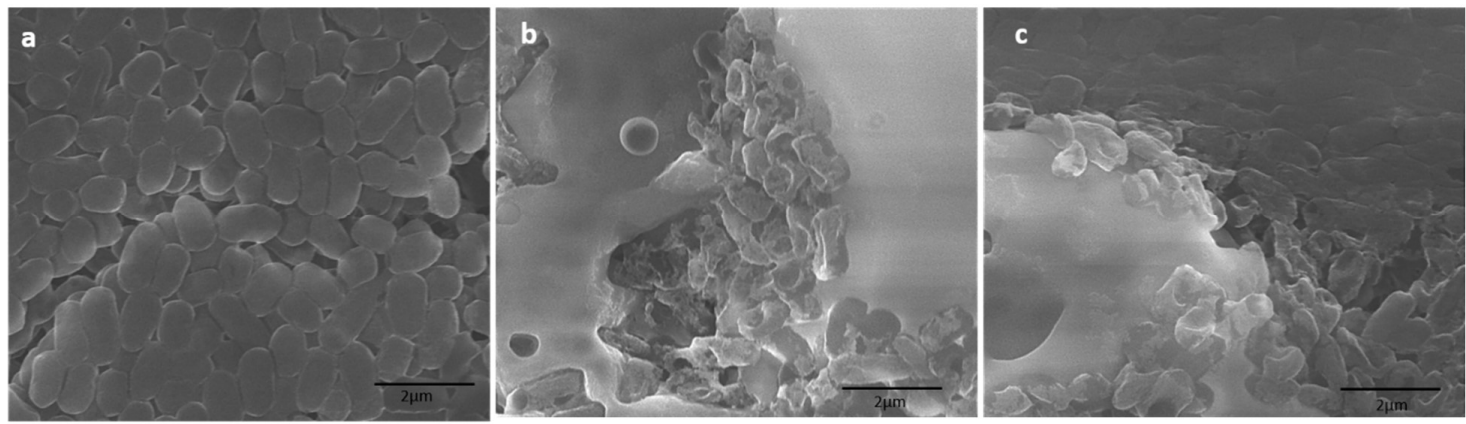

Figure 7. SEM micrographs of E. coli: (a) control (untreated cells); (b) Ag NPs at $100 \mu \mathrm{g} / \mathrm{mL}$; (c) $\mathrm{TiO}_{2}$ NPs at $100 \mu \mathrm{g} / \mathrm{mL}$.

On the other hand, the control cells (untreated) S. aureus cells were found in normal coccus shape, with a smooth and continuous cell surface (Figure 8a). Contrary to this, the treated S. aureus cells were irregular in shape and had a distorted cell surface. Both the samples, Ag NPs and $\mathrm{TiO}_{2} \mathrm{NPs}_{\mathrm{s}}$ had almost similar effects on Gram-positive cells. The cell surface was seen as irregular with a distorted cellular surface. The obtained results suggested that the E. coli cells were more severally affected as compared to $S$. aureus, when treated with Ag NPs (Figure 8b,c).
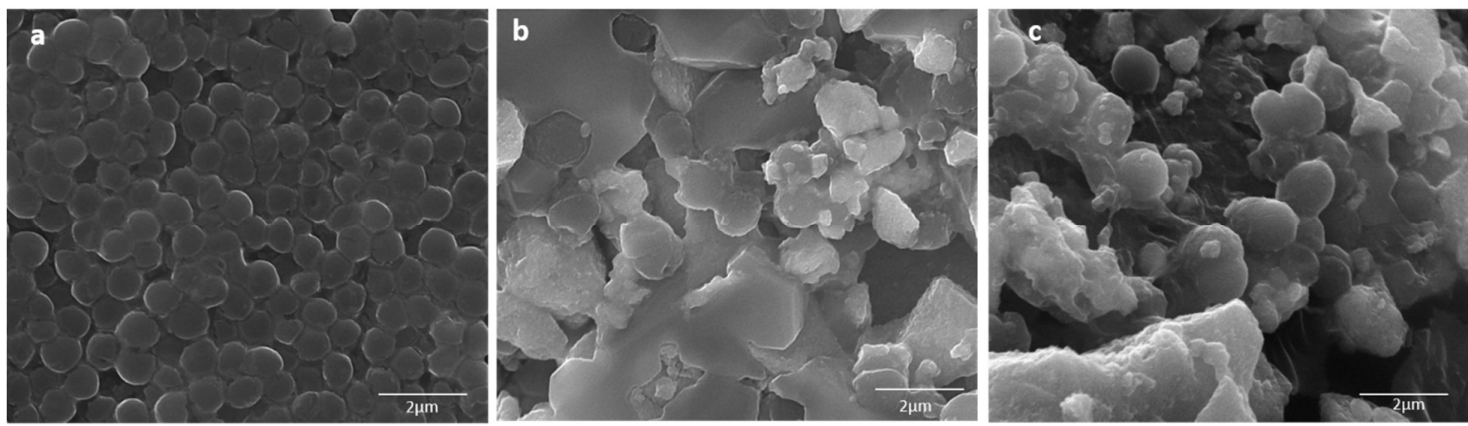

Figure 8. SEM micrographs of S. aureus: (a) control (untreated cells); (b) Ag NPs at $100 \mu \mathrm{g} / \mathrm{mL}$; (c) $\mathrm{TiO}_{2} \mathrm{NPs}$ at $100 \mu \mathrm{g} / \mathrm{mL}$.

The obtained results demonstrated the significant activity with Ag NPs, which could be owing to their smaller size of $10-20 \mathrm{~nm}$ in comparison to $\mathrm{TiO}_{2} \mathrm{NPs}$, ranging in size from $80-120 \mathrm{~nm}$. The enhanced activity could be also due to the efficient attachment of spherical-shaped Ag NPs to the cellular surface, which could play a vital role in achieving good bactericidal activity. Although there are several reports about the antimicrobial action of silver nanoparticles, the actual mode of action is still unclear [39,40]. Some studies speculate the interaction of physical entities and electrostatic forces between the positively charged NPs and the negative charge on the cell surface of bacteria [41,42]. The potential of Ag NPs as antimicrobials can be credited to various possible metabolic processes, like inactivation of enzymes and proteins, degradation of DNA, etc. [35]. The future prospectus of these NPs lies in their relatively smaller size and increased surface area, which might have a huge impact on metabolic processes like respiration, energy generation and permeability to pathogens [41]. Ag NPs are reported to easily attack proteins which contain phosphorous and sulfur as the cell constituent and genetic material, leading to cell lysis [3,7]. Such properties of Ag NPs have potential for the development of effective antimicrobial drugs for application in food packaging materials and other durable polymeric materials. 
Quite recently, the antibacterial activity of green-synthesized $\mathrm{TiO}_{2} \mathrm{NPs}$ has been reported against two pathogens, E. coli and S. aureus [38]. Lusvardi et al. demonstrated the formation of spherical aggregates of $\mathrm{TiO}_{2} \mathrm{NPs}$, having a profound activity in the reduction of colony count of a bacterial strain Pseudomonas [43]. From the above results, it becomes clear that the synthesized NPs by a green approach is not only environmentally friendly, but also has a great future in pharmaceutical and biomedical industries.

\subsection{Anticancer Activity of Synthesized NPs}

The impact of biosynthesized NPs was examined for microscopic observations and by an MTT assay. Both $\mathrm{TiO}_{2}$ and $\mathrm{Ag}$ NPs showed dose-dependent effects on cancer cell survivability, as examined by MTT assay. The treatment of $\mathrm{AgNP}_{3}$ also showed strong cytotoxic effects on cancer cell viability, as a larger majority of the cells were found dead after treatments of lower than $0.5 \mu \mathrm{g} / \mathrm{mL}$ (Figure 9A). The treatment exhibited significant alterations in cell morphology and the cell nucleus, as revealed by DAPI staining. Clear evidence of condensation and disintegration of the nucleus was seen, with lots of cancer cells found dead during the observation. NP treatment caused significant loss of nuclear staining as compared to control cells (Figure 9B). Data represented are the means \pm SD of three replicated experiments. No significant damage was found in the control group.

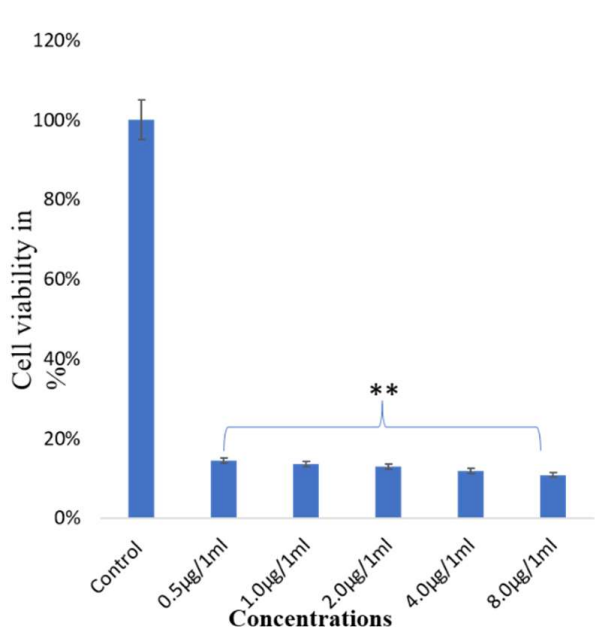

A
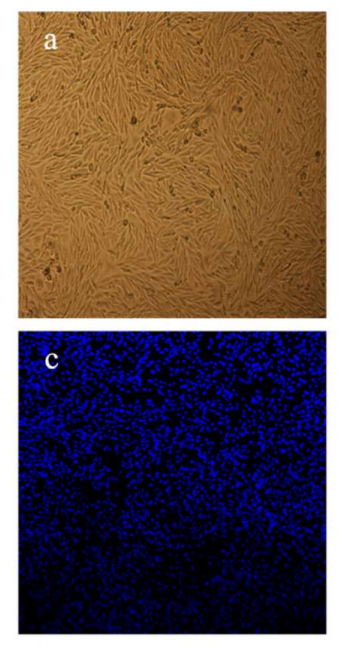
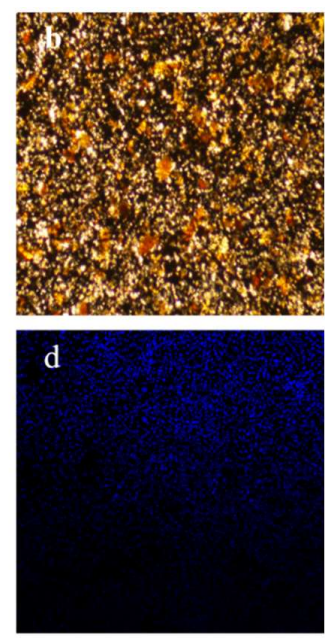

B

Figure 9. Cell viability by MTT Assay. The HCT-116 cells treated with different concentrations of Ag NPs after $48 \mathrm{~h}$ (A). (B). Cell morphology of HCT-116 cells on treatment with (a) Ag NPs control and (b) treated with $8.0 \mu \mathrm{g} / \mathrm{mL}$, analyzed by a light microscope. (c) Control and (d) treated with $8.0 \mu \mathrm{g} / \mathrm{mL}$ analyzed by a confocal scanning microscope. Difference between two treatment groups were analysed by student's t test where ${ }^{* *} p<0.01$.

The treatment with $\mathrm{TiO}_{2} \mathrm{NPs}$ also showed strong cytotoxic effects on cancer cell viability as a larger majority of the cells were found dead after treatments of lower than $0.5 \mu \mathrm{g} / \mathrm{mL}$ (Figure 10A). Significant changes in cell structure and nucleus were depicted by DAPI staining. The nuclear disintegration and condensation were indicated, with many dead cells seen. Control cells were found unaffected during treatment (Figure 10B).

Ag NPs have been reported to activate the apoptotic pathway via generation of free oxygen radicals, which result in antitumor and antiproliferative effects. Such nanomaterials that have antiangiogenic activities are known for promising abilities to alter the mechanism of proteins that are expressed abnormally $[44,45]$. Additionally, $\mathrm{TiO}_{2} \mathrm{NPs}$ synthesized via green methods have also been reported to possess antiproliferative activity against cell lines such as the $\mathrm{Mg} 63$ osteosarcoma and rat embryo fibroblast lines [46,47]. However, the exact mechanism of cancer cell death at the molecular level is still to be fully known. Therefore, it would be fascinating to unravel the apoptotic pathways involved in 
$\mathrm{TiO}_{2}$ and Ag NP-mediated cancer cell death. Interestingly, there are several reports of NPs that are known to cause nuclear fragmentation and disintegration in various cancer cell lines [48].

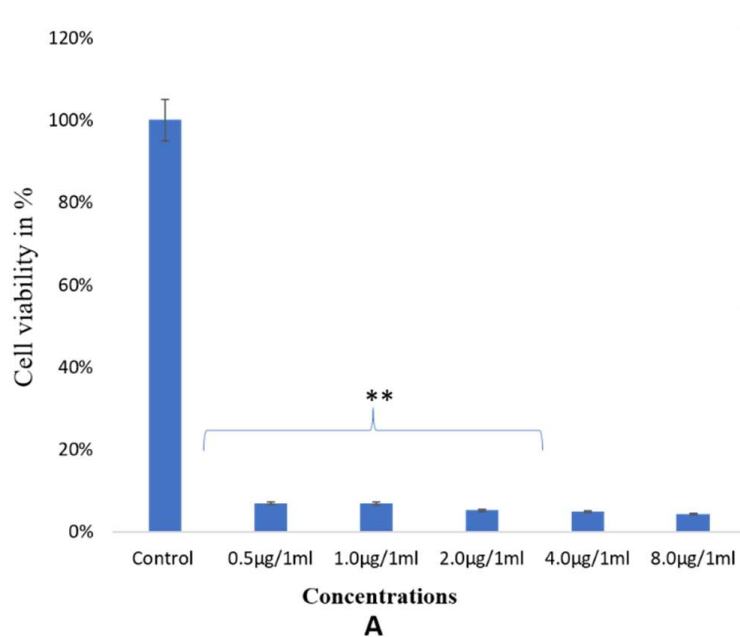

A
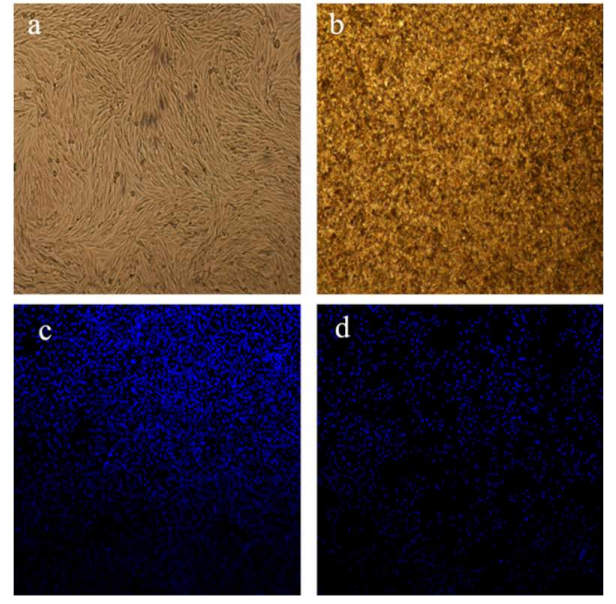

B

Figure 10. Cell viability by MTT Assay. The HCT-116 cells treated with different concentrations of $\mathrm{TiO}_{2}$ NPs after $48 \mathrm{~h}$ (A). Cell morphology of HCT-116 cells on treatment with $\mathrm{TiO}_{2} \mathrm{NPs}$ (B). (a) control and (b) treated with $8.0 \mu \mathrm{g} / \mathrm{mL}$, analyzed by a light microscope. (c) Control and (d) treated $8.0 \mu \mathrm{g} / \mathrm{mL}$ analyzed by a confocal scanning microscope. Difference between two treatment groups were analysed by student's $\mathrm{t}$ test where ${ }^{* *} p<0.01$.

\section{Conclusions}

The aqueous extract of $F$. fomentarius from Kashmir Himalaya mediated the synthesis of $\mathrm{TiO}_{2}$ and Ag NPs with varying sizes and shapes. The chemical environment of NPs and morphological features were characterized using different characterization tools. The antibacterial and anticancer activity depicted the significant effect of NPs on the tested cells. Hence, the present study supports the green synthesis of $\mathrm{TiO}_{2}$ and $\mathrm{Ag}$ NPs, using a wild mushroom, as an environmentally sustainable approach.

Supplementary Materials: The following are available online at http://www.mdpi.com/2218-273X/10/4/622/s1, Figure S1: Phylogenetic relationship of Fomes fomentarius (MK635351) ITS sequencnces with other related members based on maximum likelihood method inferred from ITS sequences. Table S1: STUDY AREA.

Author Contributions: S.R., Z.R. conceptualized and designed the study, S.R., R.F., S.M.A., F.A.K., R.J. and Z.A. carried out the experiments and prepared all figures. S.R., V.R., M.A.S. and R.A.J. discussed the results and wrote the first draft. F.A.K., H.S. and S.R. revised and edited the manuscript. All authors have read and agreed to the published version of the manuscript.

Funding: Financial support is acknowledged from Deanship of Scientific Research, Imam Abdulrahman Bin Faisal University, Dammam, Saudi Arabia, under Project No 2019-072-IRMC.

Conflicts of Interest: No potential conflict of interest was reported by the authors.

\section{References}

1. Vetchinkina, E.; Loshchinina, E.; Kupryashina, M.; Burov, A.; Pylaev, T.; Nikitina, V. Green synthesis of nanoparticles with extracellular and intracellular extracts of basidiomycetes. PeerJ 2018, 6, e5237. [CrossRef] [PubMed]

2. Prabhu, S.; Poulose, E.K. Silver nanoparticles: Mechanism of antimicrobial action, synthesis, medical applications, and toxicity effects. Int. Nano Lett. 2012, 2, 32. [CrossRef]

3. Griffith, M.; Udekwu, K.; Gkotzis, S.; Mah, T.; Alarcon, E. Silver Nanoparticle Applications. In the Fabrication and Design of Medical and Biosensing Devices; Springer International Publishing: Cham, Switzerland, 2015.

4. Wei, L.; Lu, J.; Xu, H.; Patel, A.; Chen, Z.-S.; Chen, G. Silver nanoparticles: Synthesis, properties, and therapeutic applications. Drug Discov. Today 2015, 20, 595-601. [CrossRef] 
5. Dobrucka, R. Synthesis of titanium dioxide nanoparticles using Echinacea purpurea herba. Iran. J. Pharm. Res. 2017, 16, 756 .

6. Peng, D.; Zhang, J.; Liu, Q.; Taylor, E.W. Size effect of elemental selenium nanoparticles (Nano-Se) at supranutritional levels on selenium accumulation and glutathione S-transferase activity. J. Inorg. Biochem. 2007, 101, 1457-1463. [CrossRef] [PubMed]

7. Ivask, A.; Kurvet, I.; Kasemets, K.; Blinova, I.; Aruoja, V.; Suppi, S.; Vija, H.; Käkinen, A.; Titma, T.; Heinlaan, M.; et al. Size-Dependent Toxicity of Silver Nanoparticles to Bacteria, Yeast, Algae, Crustaceans and Mammalian Cells In Vitro. PLoS ONE 2014, 9, e102108. [CrossRef] [PubMed]

8. Shang, L.; Nienhaus, K.; Nienhaus, G.U. Engineered nanoparticles interacting with cells: Size matters. J. Nanobiotechnol. 2014, 12, 5. [CrossRef]

9. Li, W.; Xu, X.; Li, W.; Liu, P.; Zhao, Y.; Cen, Q.; Chen, M. One-step synthesis of Ag nanoparticles for fabricating highly conductive patterns using infrared sintering. J. Mater. Res. Technol. 2020, 9, 142-151. [CrossRef]

10. Chin, S.; Park, E.; Kim, M.; Bae, G.-N.; Jurng, J. Synthesis and photocatalytic activity of $\mathrm{TiO}_{2}$ nanoparticles prepared by chemical vapor condensation method with different precursor concentration and residence time. J. Colloid Interface Sci. 2011, 362, 470-476. [CrossRef]

11. Narayanan, K.B.; Sakthivel, N. Green synthesis of biogenic metal nanoparticles by terrestrial and aquatic phototrophic and heterotrophic eukaryotes and biocompatible agents. Adv. Colloid Interface Sci. 2011, 169, 59-79. [CrossRef]

12. Vetchinkina, E.P.; Loshchinina, E.A.; Vodolazov, I.R.; Kursky, V.F.; Dykman, L.A.; Nikitina, V.E. Biosynthesis of nanoparticles of metals and metalloids by basidiomycetes. Preparation of gold nanoparticles by using purified fungal phenol oxidases. Appl. Microbiol. Biotechnol. 2017, 101, 1047-1062. [CrossRef] [PubMed]

13. Ahmed, S.; Annu; Ikram, S.; Yudha, S.S. Biosynthesis of gold nanoparticles: A green approach. J. Photochem. Photobiol. B Biol. 2016, 161, 141-153. [CrossRef]

14. Molnár, Z.; Bódai, V.; Szakacs, G.; Erdélyi, B.; Fogarassy, Z.; Sáfrán, G.; Varga, T.; Kónya, Z.; Tóth-Szeles, E.; Szúcs, R. Green synthesis of gold nanoparticles by thermophilic filamentous fungi. Sci. Rep. 2018, 8, 3943. [CrossRef] [PubMed]

15. Rehman, S.; Jermy, B.R.; Akhtar, S.; Borgio, J.F.; Abdul Azeez, S.; Ravinayagam, V.; Al Jindan, R.; Alsalem, Z.H.; Buhameid, A.; Gani, A. Isolation and characterization of a novel thermophile; Bacillus haynesii, applied for the green synthesis of ZnO nanoparticles. Artif. Cells Nanomed. Biotechnol. 2019, 47, 2072-2082. [CrossRef] [PubMed]

16. Gudikandula, K.; Vadapally, P.; Charya, M.S. Biogenic synthesis of silver nanoparticles from white rot fungi: Their characterization and antibacterial studies. OpenNano 2017, 2, 64-78. [CrossRef]

17. Mohseni, M.S.; Khalilzadeh, M.A.; Mohseni, M.; Hargalani, F.Z.; Getso, M.I.; Raissi, V.; Raiesi, O. Green synthesis of Ag nanoparticles from pomegranate seeds extract and synthesis of Ag-Starch nanocomposite and characterization of mechanical properties of the films. Biocatal. Agric. Biotechnol. 2020, 25, 101569. [CrossRef]

18. Thakur, B.; Kumar, A.; Kumar, D. Green synthesis of titanium dioxide nanoparticles using Azadirachta indica leaf extract and evaluation of their antibacterial activity. South Afr. J. Bot. 2019, 124, 223-227. [CrossRef]

19. Zied, D.C.; Pardo-Giménez, A. Edible and Medicinal Mushrooms: Technology and Applications; John Wiley \& Sons: Hoboken, NJ, USA, 2017.

20. Krueger, D. Monographic Studies in the Genus Polyporus (Basidiomycotina). Available online: https: //trace.tennessee.edu/utk_graddiss/2135/ (accessed on 7 March 2020).

21. Castro, M.E.; Cottet, L.; Castillo, A. Biosynthesis of gold nanoparticles by extracellular molecules produced by the phytopathogenic fungus Botrytis cinerea. Mater. Lett. 2014, 115, 42-44. [CrossRef]

22. Balashanmugam, P.; Santhosh, S.; Giyaullah, H.; Balakumaran, M.; Kalaichelvan, P. Mycosynthesis, characterization and antibacterial activity of silver nanoparticles from Microporusxanthopus: A macro Mushroom. Int. J. Innov. Res. Sci. Eng. Technol. 2013, 2, 6262-6270.

23. Mohanta, Y.; Nayak, D.; Biswas, K.; Singdevsachan, S.; Abd_Allah, E.; Hashem, A.; Alqarawi, A.; Yadav, D.; Mohanta, T. Silver nanoparticles synthesized using wild mushroom show potential antimicrobial activities against food borne pathogens. Molecules 2018, 23, 655. [CrossRef]

24. Felsenstein, J. PHYLIP (Phylogeny Inference Package), Version 3.5 c. Available online: http://www.dbbm. fiocruz.br/molbiol/main.html (accessed on 7 March 2020). 
25. Dresch, P.; Rosam, K.; Grienke, U.; Rollinger, J.M.; Peintner, U. Fungal strain matters: Colony growth and bioactivity of the European medicinal polypores Fomes fomentarius, Fomitopsis pinicola and Piptoporus betulinus. AMB Express 2015, 5, 4. [CrossRef] [PubMed]

26. Rehman, S.; Ansari, M.A.; Alzohairy, M.A.; Alomary, M.N.; Jermy, B.R.; Shahzad, R.; Tashkandi, N.; Alsalem, Z.H. Antibacterial and Antifungal Activity of Novel Synthesized Neodymium-Substituted Cobalt Ferrite Nanoparticles for Biomedical Application. Processes 2019, 7, 714. [CrossRef]

27. Khan, F.; Akhtar, S.; Almofty, S.; Almohazey, D.; Alomari, M. FMSP-nanoparticles induced cell death on human breast adenocarcinoma cell line (MCF-7 Cells): Morphometric analysis. Biomolecules 2018, 8, 32. [CrossRef] [PubMed]

28. Anthony, K.J.P.; Murugan, M.; Jeyaraj, M.; Rathinam, N.K.; Sangiliyandi, G. Synthesis of silver nanoparticles using pine mushroom extract: A potential antimicrobial agent against E. coli and B. subtilis. J. Ind. Eng. Chem. 2014, 20, 2325-2331. [CrossRef]

29. Khatami, M.; Sharifi, I.; Nobre, M.A.; Zafarnia, N.; Aflatoonian, M.R. Waste-grass-mediated green synthesis of silver nanoparticles and evaluation of their anticancer, antifungal and antibacterial activity. Green Chem. Lett. Rev. 2018, 11, 125-134.

30. Lokhande, A.; Babar, P.; Karade, V.; Jang, J.; Lokhande, V.; Lee, D.; Kim, I.-C.; Patole, S.; Qattan, I.; Lokhande, C. A viable green route to produce Ag nanoparticles for antibacterial and electrochemical supercapacitor applications. Mater. Today Chem. 2019, 14, 100181. [CrossRef]

31. Manzoor-ul-Haq, R.V.; Singh, D.; Singh, A.K.; Ninganagouda, S.; Hiremath, J. Dried mushroom Agaricus bisporus mediated synthesis of silver nanoparticles from Bandipora District (Jammu and Kashmir) and their efficacy against methicillin resistant Staphylococcus aureus (MRSA) strains. Nanosci. Nanotechnol. Int. J. 2015, 5, 1-8.

32. Ravichandran, A.; Subramanian, P.; Manoharan, V.; Muthu, T.; Periyannan, R.; Thangapandi, M.; Ponnuchamy, K.; Pandi, B.; Marimuthu, P.N. Phyto-mediated synthesis of silver nanoparticles using fucoidan isolated from Spatoglossum asperum and assessment of antibacterial activities. J. Photochem. Photobiol. B Biol. 2018, 185, 117-125. [CrossRef]

33. Kareem, A.A.; Al-Hamadani, A.H. Combination Effect of Edible Mushroom-Sliver Nanoparticles and Antibiotics against selected Multidrug Biofilm Pathogens. Iraq Med. J. 2018, 1, 68-74.

34. Nithya, R.; Ragunathan, R. Synthesis of silver nanoparticle using Pleurotus sajor caju and its antimicrobial study. Dig. J. Nanomater. Biostruct. 2009, 4, 623-629.

35. Birla, S.; Tiwari, V.; Gade, A.; Ingle, A.; Yadav, A.; Rai, M. Fabrication of silver nanoparticles by Phoma glomerata and its combined effect against Escherichia coli, Pseudomonas aeruginosa and Staphylococcus aureus. Lett. Appl. Microbiol. 2009, 48, 173-179. [CrossRef] [PubMed]

36. Panáček, A.; Smékalová, M.; Kilianová, M.; Prucek, R.; Bogdanová, K.; Večeřová, R.; Kolář, M.; Havrdová, M.; Płaza, G.A.; Chojniak, J. Strong and nonspecific synergistic antibacterial efficiency of antibiotics combined with silver nanoparticles at very low concentrations showing no cytotoxic effect. Molecules 2016, 21, 26. [CrossRef] [PubMed]

37. Balaji Raja, R.; Singh, P. Synergistic effect of silver nanoparticles with the cephalexin antibiotic against the test strains. Biores Bull. 2012, 2, 171-179.

38. Swathi, N.; Sandhiya, D.; Rajeshkumar, S.; Lakshmi, T. Green synthesis of titanium dioxide nanoparticles using Cassia fistula and its antibacterial activity. Int. J. Res. Pharm. Sci. 2019, 10, 856-860. [CrossRef]

39. Ashour, A.; El-Batal, A.I.; Maksoud, M.A.; El-Sayyad, G.S.; Labib, S.; Abdeltwab, E.; El-Okr, M. Antimicrobial activity of metal-substituted cobalt ferrite nanoparticles synthesized by sol-gel technique. Particuology 2018, 40, 141-151. [CrossRef]

40. Al-Bahrani, R.; Raman, J.; Lakshmanan, H.; Hassan, A.A.; Sabaratnam, V. Green synthesis of silver nanoparticles using tree oyster mushroom Pleurotus ostreatus and its inhibitory activity against pathogenic bacteria. Mater. Lett. 2017, 186, 21-25. [CrossRef]

41. Anandan, K.; Rajendran, V. Size controlled synthesis of $\mathrm{SnO}_{2}$ nanoparticles: Facile solvothermal process. J. Non-Oxide Glasses 2010, 2, 83-89.

42. Wang, C.; Kim, Y.J.; Singh, P.; Mathiyalagan, R.; Jin, Y.; Yang, D.C. Green synthesis of silver nanoparticles by Bacillus methylotrophicus, and their antimicrobial activity. Artif. Cells Nanomed. Biotechnol. 2016, 44, 1127-1132. 
43. Lusvardi, G.; Barani, C.; Giubertoni, F.; Paganelli, G. Synthesis and characterization of $\mathrm{TiO}_{2}$ nanoparticles for the reduction of water pollutants. Materials 2017, 10, 1208. [CrossRef]

44. Gurunathan, S.; Lee, K.J.; Kalishwaralal, K.; Sheikpranbabu, S.; Vaidyanathan, R.; Eom, S.H. Antiangiogenic properties of silver nanoparticles. Biomaterials 2009, 30, 6341-6350. [CrossRef]

45. Martins, D.; Frungillo, L.; Anazzetti, M.C.; Melo, P.S.; Durán, N. Antitumoral activity of L-ascorbic acid-polyD,L-(lactide-co-glycolide) nanoparticles containing violacein. Int. J. Nanomed. 2010, 5, 77-85. [CrossRef]

46. Chatterjee, A.; Nishanthini, D.; Sandhiya, N.; Abraham, J. Biosynthesis of titanium dioxide nanoparticles using Vigna radiata. Asian J. Pharm. Clin. Res. 2016, 9, 1-4.

47. Suker, D.K.; Albadran, R.M. Cytotoxic effects of titanium dioxide nanoparticles on rat embryo fibroblast REF-3 cell line in vitro. Eur. J. Exp. Biol. 2013, 3, 354-363.

48. Barabadi, H.; Ovais, M.; Shinwari, Z.K.; Saravanan, M. Anti-cancer green bionanomaterials: Present status and future prospects. Green Chem. Lett. Rev. 2017, 10, 285-314. [CrossRef]

(C) 2020 by the authors. Licensee MDPI, Basel, Switzerland. This article is an open access article distributed under the terms and conditions of the Creative Commons Attribution (CC BY) license (http://creativecommons.org/licenses/by/4.0/). 